\title{
ANALISIS PERFORMA AGILITY DAN ENDURANCE ATLET SENAM AEROBIK PADA MASA PANDEMI COVID 19
}

\author{
Puspodari ${ }^{1}$, Septyaning Lusianti ${ }^{2}$,Rendhitya Prima Putra ${ }^{3}$ \\ 1,2,3Universitas Nusantara PGRI Kediri \\ E-mail: puspodari@unpkediri.ac.id11, lusi.septya@unpkdr.ac.id², \\ rendhitya@webmail.unpkediri.ac.id ${ }^{3}$ \\ DOI: https://doi.org/10.36526/kejaora.v6i2.1567
}

\begin{abstract}
ABSTRAK
Senam aerobik merupakan serangkaian gerak yang dipilih secara sengaja dengan mengikuti irama musik yang telah dipilih sehingga melahirka ketentuan ritmis, continue dengan durasi tertentu. Performa agility dan endurance merupakan kondisi fisik spesifik pada cabang olahraga senam aerobik ditinjau dari karakteristik gerak. Agility (kelincahan) merupakan suatu kemampuan tubuh untuk merubah arah dan posisi tubuh dengan cepat dan tepat pada waktu sedang bergerak, tanpa kehilangan keseimbangan dan kesadaran akan posisi tubuhnya. Sedangkan endurance (daya tahan) adalah kemampuan organisme untuk mengerahkan dirinya sendiri dan tetap aktif untuk jangka waktu yang lama. Tujuan dari penelitian ini adalah untuk mengetahui performa agility dan endurance pada atlet senam aerobik pada masa pandemi covid19 melalui tes dan pengukuran. Desain penelitian ini adalah deskriptif kuantitatif dengan metode survei. Subjek dalam penelitian ini adalah 15 atlet senam aerobik yang tergabung dalam puslatkot kota Kediri. Teknik analisis data yang digunakan adalah deskriptif presentase. Hasil penelitian ini menunjukkan bahwa atlet senam aerobik puslatkot kota Kediri memiliki performa agility rata-rata dalam kategori sedang diantaranya 1 orang masuk dalam kategori baik (6,67\%), 2 orang masuk dalam kategori baik sekali $(13,33 \%), 8$ orang masuk dalam kategori sedang $(53,33 \%), 4$ orang masuk kategori kurang $(26,67 \%)$, dan sejumlah 0 orang masuk dalam kategori kurang sekali $(0 \%)$. Sedangkan rata-rata performa endurance adalah sedang diantaranya 0 orang masuk dalam kategori baik sekali $(0 \%), 3$ orang masuk dalam kategori baik $(20 \%), 9$ orang masuk dalam kategori sedang $(60 \%), 2$ orang masuk dalam kategori kurang $(13,33 \%)$ dan 1 orang masuk dalam kategori kurang sekali $(6,67 \%)$. Kesimpulan yang didapat dari penelitian ini adalah performa agility dan endurance atlet senam aerobik rata-rata dalam kategori sedang pada masa pandemi covid19. Saran yang dapat diberikan adalah pelatih perlu memberikan program latihan yang baik dan sesuai untuk meningkatkan performa agility dan endurance khususnya pada masa pandemi covid19.
\end{abstract}

Kata Kunci: Agility, Endurance, Senam Aerobik, Covid 19

\section{PENDAHULUAN}

Olahraga memberikan kontribusi penting bagi perkembangan sosial ekonomi masyarakat. Namun, sejak pandemi Coronavirus Disease 2019 (covid-19) menyebar, pemerintah mulai memberlakukna protokol kesehatan secara ketat, seperti peraturan menjaga jarak dan pembatasan sosial berskala besar tentunya sangat mengganggu perhelatan olahraga dan sejumlah aspek lainnya. Dengan ditundanya sejumlah perhelatan olahraga berskala besar, atlet profesional terpaksa menjadwal ulang program latihan agar kebugaran tubuhnya tetap terjaga selama berada dirumah (Kardiyanto, 2020). Keadaan ini tentunya akan berpengaruh pada perubahan kondisi fisik atlet akibat dari adaptasi latihan yang mereka lakukan.

Kondisi fisik merupakan sebuah gambaran dari keadaan manusia yang dilihat dari keadaan fisik (Harsono, 2021). Kondisi fisik yang baik adalah penentu kebugaran seseorang. Kebugaran merupakan faktor penting bagi seseorang untuk tetap sehat dan memiliki tingkat imunitas yang baik. Dengan 
Jurnal Kejaora: Jurnal Kesehatan Jasmani dan Olah Raga

ISSN: 2541-5042 (Online)

ISSN: 2503-2976 (Print)

Volume 6 Nomor 2, Edisi November 2021

tingkat imunitas yang baik, seseorang akan terhindar dari penyakit atau lebih cepat proses pemulihan ketika mengalami sakit. Adanya pandemi covid19 memberikan ancaman kesehatan bagi masyarakat dunia. Oleh karena itu masyarakat dihimbau memperhatikan protokol kesehatan, menjaga imunitas tubuh dan tetap berdo'a. Selama pandemi covid19 semua kegiatan tatap muka dibatasi sehingga membuat aktivitas fisik yang dilakukan secara bersama-sama semakin menurun. Proses latihan yang dilakukan selama pandemi covid19 dengan daring melalui platform zoom yang diawasi oleh pelatih. Namun seringkali masalah jaringan menjadi kendala, sehingga pelatih tidak dapat mengontrol dengan baik ketepatan gerak yang dilakukan oleh atlet. Apabila hal ini diabaikan akan mengakibatkan kurangnya kondisi fisik yang bedampak pada kebugaran jasmani dan prestasi seorang atlet yang harus selalu memantau kondisi fisiknya. Dalam mencapai sebuah prestasi tertinggi, tentunya harus melalui berbagai proses pembinaan, latihan teratur dan didukung kemampuan atlet dengan status fisik yang baik (Subekti et al., 2021). Pada cabang olahraga senam aerobik, faktor kondisi fisik merupakan faktor yang fundamental seorang atlet yang harus dimiliki sebagai dasar pengembangan kualitas dan perlu ditingkatkan untuk mendukung performa.

Performa agility (kelincahan) dan endurance (daya tahan) bisa dikatakan sebagai unsur fisik spesifik pada cabang olahraga senam aerobik. Agility (kelincahan) adalah kemampuan mengubah arah tubuh secara cepat tanpa adanya gangguan keseimbangan (Karminovsia, 2016). Kelincahan adalah kemampuan seseorang untuk mengubah arah dengan cepat tanpa kehilangan (Candrawati et al., 2017). Pendapat Amiq (2016) kelincahan adalah kemampuan seseorang merubah posisi berbeda dalam keadaan bergerak. Sedangkan menurut Acar \& Eler (2019) kelincahan adalah kemampuan mengubah arah dengan cepat dengan menjaga keseimbangan tubuh tanpa kehilangan kecepatannya. Seseorang yang mampu mengubah arah dari posisi awal ke posisi yang berbeda dalam kecepatan tinggi dengan

koordinasi gerak yang baik berarti kelincahannya cukup tinggi.

Daya tahan sebagai unsur utama dalam melatih kebugaran jasmani. Daya tahan adalah keadaan atau kondisi tubuh yang mampu untuk bekera dalam waktu yang lama, tanpa mengalami kelelahan yang berlebihan (Kuswandi, 2012). Daya tahan tubuh diperlukan untuk beraktivitas seharihari, dengan daya tahan tubuh yang baik maka aktivitas sehari-hari tidak akan mengalami kelelahan yang begitu berat. Daya tahan sangat berhubungan dengan pernafasan jantung dan peredaran darah (Irwandi \& Aprizalmi, 2016). Kebugaran jasmani memberikan kemampuan kepada seseorang untuk melakukan pekerjaan yang produktif sehari-harinya tanpa adanya kelelahan yang berlebihan. Kebugaran kardiorespirasi yang rendah dapat meningkatkan resiko kematian akibat penyakit jantung dan hipertensi (Irianto \& Hasnah, 2018). Unsur yang mempengaruhi kesehatan fisik adalah daya tahan kardiorespirasi (Kusnanik et al., 2020). Kesehatan kardiovaskuler yang ideal merupakan konsep yang baik berdasarkan perilaku kesehatan ideal (tidak merokok, indeks massa tubuh $25 \mathrm{~kg} / \mathrm{m} 2$ ), aktivitas fisik pada tingkat tujuan, dan diet yang konsisten dengan rekomendasi pedoman diet dan faktor kesehatan ideal (kolesterol total yang tidak melebihi $200 \mathrm{mg} / \mathrm{dL}$, tekanan darah yang tidak melebihi $120 / 80 \mathrm{mmHg}$, danglukosa darah puasa $100 \mathrm{mg} / \mathrm{dL}$ (LloydJones et al., 2010).

Salah satu cara untuk menilai agility (kelincahan) adalah tes shuttle run. Sedangkan untuk menilai daya tahan kardiorespirasi seseorang adalah dengan mengukur nilai VO2Max dengan tujuan mengukur kapasitas jantung, paru, dan darah untuk mengangkut oksigen ke otot yang bekerja dan mengukur penggunaan oksigen oleh otot (Nugraheni et al., 2017) menggunakan tes MFT (Multistage Fitness Test) digunakan untuk menganalisis performa endurance.

\section{METODE}

Penelitian ini merupakan penelitian survey dengan pendekatan deskripstif 
Jurnal Kejaora: Jurnal Kesehatan Jasmani dan Olah Raga

ISSN: 2541-5042 (Online)

ISSN: 2503-2976 (Print)

Volume 6 Nomor 2, Edisi November 2021

kuantitatif, mengukur kemampuan performa agility dan endurance atlet senam aerobik Puslatkot kota Kediri yang berjumlah 15 atlet terdiri dari 15 atlet putri. Metode yang digunakan adalah metode survei dengan teknik tes dan pengukuran. Instrumen atau alat ukur yang digunakan diantaranya tes shuttle run untuk mengukur kelincahan dan tes Multistage Fitness Test untuk mengukur daya tahan jantung atau endurance. Data yang diperoleh akan dideskripsikan kemudian dianalisis. Penelitian ini menggambarkan kondisi tingkat performa agility dan endurance atlet senam aerobik pada masa pandemi covid19.

\section{HASIL DAN PEMBAHASAN}

Tidak dapat dipungkiri bahwa pada masa pandemi seperti saat ini atlet tidak bisa berlatih dengan maksimal. Latihan yang terbatas dan tidak maksimal menjadikan masalah kondisi fisik atlet patut dipertanyakan. Berbagai kondisi tempat tinggal atlet yang susah mendapatkan akses sinyal dengan baik akan menghambat proses latihan yang dilakukan secara daring. Selain itu karena adanya anjuran pemerintah untuk stay at home membuat program latihan para atlet sempat tidak terkontrol. Kondisi fisik merupakan pondasi dasar seorang atlet untuk bisa mendapatkan prestasi yang cemerlang (Sulistiono, 2014).

Kondisi fisik yang baik tentu sangat diperlukan oleh setiap manusia, terlebih oleh seorang atlet untuk memperoleh ketangkasan serta kekuatan melaksanakan program fisik guna mencapai prestasi yang maksimal. Dalam dunia atlet peningkatan daya tahan tubuh dianggap sangat penting, karena merupakan unsur pokok dari kondisi fisik atlet sebelum keterampilan, mobilitas gerak, penguatan otot teknik, kecepatan dan lain sebagainya (Vania et al., 2018). Kebugaran jasmani telah menjadi kebutuhan dasar atlet sehingga menjadi cermin dari kemampuan fungsi sistem di dalam tubuh yang mampu mewujudkan progres meningkatnya prestasi atlet (Sepriadi, 2017).

Deskripsi data penelitian berikut ini bertujuan untuk menggambarkan data penelitian dari subjek yang diteliti yakni tes hasil kemampuan kelincahan (agility) yang

diukur dengan shuttle run dan tes daya tahan (endurance) diukur dengan menggunakan Multistage Fitness Test (MFT) atau bleep test. Adapun deskripsi hasil performa agility dan endurance atlet senam aerobik Puslatkot kota Kediri diantaranya :

Tabel 1. Nilai Prosentase Agility

\begin{tabular}{lll}
\hline Kategori & $\begin{array}{l}\text { Prosentase } \\
(\%)\end{array}$ & Jumlah \\
\hline Baik Sekali & $6,67 \%$ & 1 \\
\hline Baik & $13,33 \%$ & 2 \\
\hline Sedang & $53,33 \%$ & 8 \\
\hline Kurang & $26,67 \%$ & 4 \\
\hline $\begin{array}{l}\text { Kurang } \\
\text { Sekali }\end{array}$ & $0 \%$ & 0 \\
\hline
\end{tabular}

Nilai prosentase pada tabel diatas menunjukkan bahwa tingkat performa agility atlet senam aerobik dengan jumlah responden 15 , diantaranya 1 orang masuk dalam kategori baik sekali (13,33\%), 8 orang masuk dalam kategori sedang $(53,33 \%), 4$ orang masuk kategori kurang $(26,67 \%)$, dan sejumlah 0 orang masuk dalam kategori kurang sekali $(0 \%)$. Berikut ini merupakan table presentase tingkat agility mengacu pada (Ahmad Muchlisin Natas Pasaribu, 2020) sebagai berikut :

Tabel 2. Deskripsi Persentase Klarifikasi Tes Shuttle Run (Ahmad Muchlisin Natas Pasaribu, 2020)

\begin{tabular}{lll}
\hline No & Nilai & Kategori \\
\hline 1 & $>14$ & Baik Sekali \\
\hline 2 & $11-14$ & Baik \\
\hline 3 & $7-10$ & Sedang \\
\hline 4 & $4-6$ & Kurang \\
\hline 5 & $<4$ & Kurang Sekali \\
\hline
\end{tabular}

Deskripsi selanjutnya terkait dengan prosentase performa endurance yang dilakukan dengan tes Multistage Fitness Test (MFT), berikut hasil deskripsinya :

Tabel 3. Nilai Prosentase Endurance

\begin{tabular}{lll}
\hline Kategori & Prosentase (\%) & Jumlah \\
\hline Baik Sekali & 0 & 0 \\
\hline Baik & 20 & 3 \\
\hline Sedang & 60 & 9 \\
\hline Kurang & 13,33 & 2 \\
\hline
\end{tabular}


Jurnal Kejaora: Jurnal Kesehatan Jasmani dan Olah Raga

ISSN: 2541-5042 (Online)

ISSN: 2503-2976 (Print)

Volume 6 Nomor 2, Edisi November 2021

\begin{tabular}{lll}
\hline $\begin{array}{l}\text { Kurang } \\
\text { Sekali }\end{array}$ & 6,67 & 1 \\
\hline
\end{tabular}

Nilai prosentase pada tabel diatas menunjukkan bahwa tingkat performa endurance atlet senam dengan jumlah responden 15 , diantaranya 0 orang masuk dalam kategori baik sekali $(0 \%), 3$ orang masuk dalam kategori baik (20\%), 9 orang masuk dalam kategori sedang $(60 \%), 2$ orang masuk dalam kategori kurang $(13,33 \%)$ dan 1 orang masuk dalam kategori kurang sekali $(6,67 \%)$. Berikut ini merupakan tabel presentase tingkat VO2Max mengacu pada norma Brianmac.

Tabel 4. Deskripsi Persentase Klarifikasi Tes VO2Max (BrianMac, 2018)

\begin{tabular}{lll}
\hline No & Nilai & Kategori \\
\hline 1 & $\geq 52,4$ & Luar Biasa \\
\hline 2 & $46,5-52,4$ & Sangat Baik \\
\hline 3 & $42,5-46,4$ & Baik \\
\hline 4 & $36,5-42,4$ & Sedang \\
\hline 5 & $33,0-36,4$ & Kurang \\
\hline 6 & $\leq 33,0$ & Sangat Kurang \\
\hline
\end{tabular}

Berdasarkan analisis data hasil performa agility dengan menggunakan instrument shuttle run mendapatkan hasil rata-rata agility atlet senam aerobik Puslatkot adalah sedang dan hasil performa endurance dengan tes Multistage Fitness Test (MFT) adalah sedang. Hal tersebut perlu mendapatkan sorotan dan tindak lanjjut dari pelatih, dikarenakan performa agility dan endurance adalah unsur kondisi fisik yang paling dibutuhkan dalam senam aerobik. Sebagaimana berdasarkan hasil penelitian bahwa dalam senam aerobik gerakangerakannya harus dilakukan dengan enerjik dan tepat, agar gerakan yang dilakukan sesuai dengan tempo musiknya sehingga performa agility sangat diperlukan. Selain itu segala sesuatu yang berkaitan denga jaringan jantung (jantung, pembuluh darah dan paru-paru) adalah jaringan utama yag digunakan oleh tubuh selama sebuah latihan aerobik (Febriyanti et al., 2018).

Untuk mengklasifikasikan seberapa prosentase untuk masing-masing kategori dengan menggunakan rumus prosentase sebagai berikut :

Menurut Sugiono (2018):

$\mathrm{P}=\mathrm{f} / \mathrm{n} \times 100$

Dimana :

$\mathrm{P} \quad=$ angka presentase

$\mathrm{F} \quad=$ frekuensi yang sedang dicari persentasenya/ kategorinya

$\mathrm{N} \quad=$ Number of cases (jumlah frekuensi/ banyaknya individu)

Beberapa hal yang perlu dilakukan untuk merespon kondisi performa kondisi fisik tersebut adalah dengan menambah latihan agility dan endurance dengan latihan yang berhubungan dengan kardiovaskuler atau meningkatkan intensitas latihan agar daya tahan otot jantung atlet senam aerobik Puslatkot kota Kediri dapat menjadi lebih baik.

\section{KESIMPULAN}

Kondisi fisik yang baik juga dapat dipengaruhi oleh gaya hidup seperti konsumsi makan, kebiasaan merokok, dan pola aktivitas fisik sehari-hari. Pola aktivitas fisik selama pandemi covid19 yang tidak terkontrol dapat mengakibatkan kondisi fisik atlet menurun. Hal ini memprediksi kemungkinan penurunan prestasi apabila atlet tidak menyesuaikan program latihan dengan rencana even olahraga yang akan diikuti.

Berdasarkan hasil analisis performa agility dan endurance atlet senam aerobik pada masa pandemi covid19 menunjukkan rata-rata performa agility atlet Puslatkot kota Kediri dalam kategori sedang. Dengan jumlah responden yang diteliti adalah 15 orang atlet. Performa agility atlet senam aerobik Puslatkot kota kediri diantaranya 1 orang masuk dalam kategori baik (6,67\%), 2 orang masuk dalam kategori baik sekali (13,33\%), 8 orang masuk dalam kategori sedang $(53,33 \%), 4$ orang masuk kategori kurang $(26,67 \%)$, dan sejumlah 0 orang masuk dalam kategori kurang sekali $(0 \%)$. Sedangkan pada performa endurance diantaranya 0 orang masuk dalam kategori baik sekali $(0 \%), 3$ orang masuk dalam kategori baik (20\%), 9 
Jurnal Kejaora: Jurnal Kesehatan Jasmani dan Olah Raga

ISSN: 2541-5042 (Online)

ISSN: 2503-2976 (Print)

Volume 6 Nomor 2, Edisi November 2021

orang masuk dalam kategori sedang (60\%), 2 orang masuk dalam kategori kurang $(13,33 \%)$ dan 1 orang masuk dalam kategori kurang sekali $(6,67 \%)$. Berdasarkan hasil analisis tersebut perlu dilakukan penambahan intensitas latihan yang berfokus pada agility dan endurance sehingga mampu menunjang atlet dalam meningkatkan hasil performa unsur kondisi fisik tersebut.

\section{UCAPAN TERIMA KASIH}

Terimakasih penulis ucapkan pada rektor Universitas Nusantara PGRI Kediri, Dekan Fakultas Keguruan Dan IImu Pendidikan dan Lembaga Penelitian dan Pengabdian kepada Masyarakat (LPPM) Universitas Nusantara PGRI Kediri, dan KONI kota Kediri yang telah memberikan dukungan dalam penelitian ini.

\section{DAFTAR PUSTAKA}

Acar, H., \& Eler, N. (2019). The Effect of Balance Exercises on Speed and Agility in Physical Education Lessons. Universal Journal of Educational Research, 7(1), 74-79. https://doi.org/10.13189/ujer.2019.070 110

Ahmad Muchlisin Natas Pasaribu, A. M. N. (2020). Tes dan Pengukuran Olahraga.

Amiq, F. (2016). Sepakbola. Malang: Universitas Negeri Malang.

BrianMac. (2018). Circuit Training. Https://Www.Brianmac.Co.Uk/Circuit.H tm.

Candrawati, S., Signa, N., Nanang, M., Eva, P., Cahya, M., \& Safira, S. (2017). The Relationship of ACTN3 Gene Plymorphisms with Agility, Explosive Power and Speed. 29(4).

Febriyanti, F., Jayadi, I., \& Wiriawan, 0. (2018). Tingkat Kondisi Fisik Member Senam Aerobik Di Sanggar " Gleonov Gym ." Journal of Sport and Exercise Science, 1(1), 8-12.

Harsono. (2021). Tinjauan Kondisi Fisik Wasit Sepakbola Pengcab PSSI Provinsi.

Irianto, I., \& Hasnah, H. (2018). The Effect Of Freeletic Sport To Vo2 Max Levels On The Freeletic Community Members In Makassar City. Nusantara Medical Science Journal, 37-41.

Irwandi, I., \& Aprizalmi, A. (2016). Hubungan Kapasitas Aerobik (Vo2max) Terhadap Keterampilan Sepakbola Pada Club Getsempena Fc Tahun 2016. Penjaskesrek Journal, 3(1).

Kardiyanto, D. W. (2020). Dampak pandemi covid-19 terhadap event olahraga dan sosial ekonomi masyarakat. Journal of Chemical Information and Modeling, 53(9), 1689-1699.

Karminovsia, L. (2016). Pengaruh Latihan Side to Side With Cone Reach dan Sode to Side With Back Rotation Terhadap Kelincahan. Program Studi Pendidikan Kepelatihan Olahraga Universitas Sebelas Negeri Semarang.

Kusnanik, N. W., Surabaya, U., Suminar, T. J., Bird, S. P., \& Southwales, B. N. (2020). The Effect of Zumba and High Impact Aerobic in Reducing Skinfold Thickness. International Conference on Research and Academic Community Services (ICRACOS 2019), 390(Icracos 2019), 165-168.

Kuswandi. (2012). Latihan Daya Tahan (Endurance Training).

Lloyd-Jones, D. M., Hong, Y., Labarthe, D., Mozaffarian, D., Appel, L. J., Van Horn, L., \& Rosamond, W. D. (2010). Defining and setting national goals for cardiovascular health promotion and disease reduction: the American Heart Association's strategic Impact Goal through 2020 and beyond. Circulation, 121(4), 586-613.

Nugraheni, H. D., Marijo, \& Indraswari, D. A. (2017). Perbedaan nilai vo 2 max antara atlet cabang olahraga permainan dan bela diri. JURNAL KEDOKTERAN DIPONEGORO, 6(2), 622-631.

Sepriadi, S. (2017). Kontribusi Status Gizi dan Kemampuan Motorik terhadap Kesegaran Jasmani Siswa Sekolah Dasar. Jurnal Keolahragaan, 5(2), 194206.

Subekti, N., Warthadi, A. N., Mujahid, H., \& Abdullah, A. (2021). Analisis Performa Speed dan Power Atlet Pencak Silat Level Elit. Jurnal Olahraga Dan Prestasi, 18, 39-45.

Sugiono. (2018). Metodologi Penelitian. 
Jurnal Kejaora: Jurnal Kesehatan Jasmani dan Olah Raga

ISSN: 2541-5042 (Online)

ISSN: 2503-2976 (Print)

Volume 6 Nomor 2, Edisi November 2021

Bandung : Alfabeta.

Sulistiono, A. A. (2014). Kebugaran jasmani siswa pendidikan dasar dan menengah di Jawa Barat. Jurnal Pendidikan Dan Kebudayaan, 20(2), 223-233.

Vania, E. R., Pradigdo, S. F., \& Nugraheni, S. . (2018). Hubungan Gaya Hidup, Status Gizi Dan Aktivitas Fisik Dengan Tingkat Kesegaran Jasmani (Studi Pada Atlet Softball Perguruan Tinggi Di Semarang Tahun 2017). JURNAL KESEHATAN MASYARAKAT, 6(1), 449-457. 